\title{
Therapeutic Water in the Poprad Valley - the Newest Development in the Polish Outer Carpathians
}

\author{
Agnieszka Operacz $^{1 *}$, Ewa Wąsik ${ }^{1}$, Mariusz Hajduga², Krzysztof Chmielowski ${ }^{1}$ \\ ${ }^{1}$ University of Agriculture in Kraków, Faculty of Environmental Engineering and Land Surveying, \\ Department of Sanitary Engineering and Water Management, \\ Al. Mickiewicza 21, 31-120 Kraków \\ ${ }^{2}$ MASSPOL Sp. z o.o., Zubrzyk 101, 33-350 Piwniczna-Zdrój
}

Received: 3 April 2017

Accepted: 23 July 2017

\begin{abstract}
Carbonated waters and waters containing carbon dioxide have long been exploited in the Polish Outer Carpathians, especially in the Krynica subunit of Magura Nappe. Exploitation of these waters in the Zubrzyk area is the latest hydrogeological development. The first boreholes were drilled in the early $21^{\text {st }}$ century. Currently, exploitation of therapeutic waters is managed by three boreholes. Two of them (Z-2 and Z-3a) have a database of several years of observation of physical and chemical parameters. The Z-8 borehole was included in exploitation only in early 2016. The Z-2 borehole takes in $\mathrm{HCO}_{3}-\mathrm{Ca}-\mathrm{Mg}-\mathrm{Na}$ carbonated water, the $\mathrm{Z}-3 \mathrm{a}$ borehole takes in $\mathrm{HCO}_{3}-\mathrm{Na}-\mathrm{Mg}-\mathrm{Ca}$ carbonated water, and the Z-8 borehole intakes $\mathrm{HCO}_{3}-\mathrm{Na}-\mathrm{Mg}$ water containing carbon dioxide.
\end{abstract}

Keywords: therapeutic water, carbonated waters, waters containing carbon dioxide, Magura Nappe

\section{Introduction}

In the Krynica Subunit - the part of Magura Nappe between Tylicz in the east and Głębokie near Piwniczna in the west - therapeutic waters known for ages occur almost everywhere. The occurrence of carbonated waters and waters containing carbon dioxide in this area have greatly contributed to tourist development of such renowned health resorts as Krynica-Zdrój, Muszyna, Piwniczna, and Żegiestów. The region is rich in natural mineral water springs that are confined to a tectonic block bounded by the Tylicz and Krynica faults [1]. At present, a number of

*e-mail: a.operacz@ur.krakow.pl commonly available sources of waters and health resort well-rooms are functioning, along with drilling boreholes producing therapeutic waters for several bottling plants.

Therapeutic waters in the Krynica subunit of the Flysh Carpathians have been broadly discussed in many aspects in numerous publications [2-7]. The carbonated waters and waters containing carbon dioxide were widely discussed by Rajchel [8-10]. However, there are practically no studies of the Krynica subunit as regards the use of therapeutic waters in the region of Zubrzyk in contrast to the Milik or Andrzejówka areas [11]. This follows directly from the fact that the first prospecting of groundwater in the area of Zubrzyk were initiated as late as in 1999. The first wells (Z-1 and Z-3) with natural water and the opening $Z-2$ with therapeutic water were drilled 
in this region as late as in 2001. There are currently nine boreholes: Z-2, Z-3a, Z-8 (property of MASSPOL), and Z-3 (property of INEX) take in therapeutic water while the remaining ones (Z-1, Z-3, Z-4, Z-5/I, and Z-11) take in regular water. All the boreholes are within the sandstone and shale facies that is referred to as sandstone from Piwniczna.

Exploitation of therapeutic waters is now conducted only within the "OG Zubrzyk" exploration region. MASSPOL Sp. z o.o. in Zubrzyk is the owner of the concession. Exploitation of therapeutic and natural water in the exploration region is managed by drilling, with borehole pumps with the parameters appropriate for the parameters of the intake and the volume of the approved exploitation resources. Exploitation is managed on the basis of the operations plan within the concession for therapeutic water exploitation, and is used for bottling purposes in Rozlewnia Wody Mineralnej MASSPOL Sp. z o.o. in Zubrzyk.

Borehole Z-3, owned by INEX, was drilled in 2005, but no drilling and prospective work have been completed during this time and the resources of the borehole were not documented, and the concession granted by the minister of the environment has expired. In April 2016 the exploitation resources of therapeutic water of the above borehole were approved, whereas exploitation is not conducted at present. The therapeutic water found in this borehole is: carbonated water $\mathrm{HCO}_{3}-\mathrm{Na}-\mathrm{Mg}$ with ca. $12 \mathrm{~g} / \mathrm{dm}^{3}$ mineralisation.

\section{Characteristics of the Krynica Subunit in the Zubrzyk Region}

The discussed area is located within the Magura Nappe in the tectonic unit called the Krynica Zone (Fig. 1). This formation reaches 2,000-2,500 $\mathrm{m}$ in thickness in the Krynica Subunit. In Poland the Magura Formation is subdivided into the following members: Piwniczna sandstone, Mniszek shale, and Poprad sandstone [12-14]. Piwniczna sandstone dates to the Eocene period and is usually thick-bedded (1-3 m) and medium grained with random sizing. $1-20 \mathrm{~cm}$ thick shale accompanies sandstone (in the floor and roof parts of the entire complex). Sandstone beds of several metres are sometimes separated by conglomerate bodies with grains up to $2 \mathrm{~cm}$ in diameter. The considerable thickness of this series is $800-1,200 \mathrm{~m}$ (Fig. 2), although in the Krynica subunit, there has always been a problem as to how to separate the Piwniczna and Poprad sandstone members of the Magura formation when the Mniszek shale member was absent. As a result, the thickness of the Piwniczna sandstone member is often overestimated [15].

The Zubrzyk area is built of quaternary formations on top of flysch formations, in a discontinuous layer of varying thickness. Quaternary formations in the discussed area are quite thick: up to $10 \mathrm{~m}$ in the Poprad Valley. These formations are in the form of gravels, clays, and fluvial sands of flood plains.
Zubrzyk is in the Piwniczna-Zdrój commune in the Małopolskie Voivodship in southern Poland. It is located in Beskid Sądecki, in the northern slope of the Poprad Valley along which Poland borders Slovakia (Fig. 1). Morphology of the area indicates strong dependence on the strength of the sub-floor rock and the run of tectonic structures with the extension of the train of hills along a NW-SE direction. Hydrographically, the study area is in the direct catchment of the Poprad Valley.

\section{Natural Groundwater}

Natural groundwater in the Zubrzyk area within the Krynica subunit occurs within quaternary and flysch formations. Quaternary formations offluvial accumulation are in the form of a regular groundwater reservoir with free surface at a depth of several metres. These are pore waters used mostly in isolated households. Fissure waters occur in flysch formations (Paleogene), mostly in sandstone beds. Pores as the pathways of circulating water are practically irrelevant due to too small dimensions and partial filling with binding material. Water-bearing rates of flysch formations in the active exchange zone depend mostly on the volume and thickness of sandstone beds, and the studies conducted in the Zubrzyk area allow an estimate of $0.8-5.0 \mathrm{~m}^{3} / \mathrm{h}$. The water-bearing level in flysch formations is fed by infiltration of rainwater through the residual cover. Groundwaters flow mostly in the directions parallel to bedding and then follow slope gradients, fissures, and interbed fractures. The E-W direction is the main direction of flow of the groundwaters in the discussed area (Fig. 1). The depth of the active exchange zone is estimated (on the basis of the executed drilling work) at $200.0 \mathrm{~m}$ b.g.1.

\section{Therapeutic Water}

Therapeutic water, recognised by dissolved minerals, includes groundwaters without chemical and microbiological pollution, with natural variability of physical and chemical properties, and which meet the conditions defined in the Geological and Mining Law [16].

Carbon dioxide of abyssal origin plays the principal role in the process of mineralisation of waters of the discussed area [17]. Natural waters, when flowing down to the areas of supply toward the drainage base or to the wells, become saturated with carbon dioxide when found along the path, become aggressive, and then easily and probably quickly become mineralised in contact with the rock environment. The atmospheric daily mean concentrations of carbon dioxide observed in southern Poland (as natural variations and increasingly caused by human impact) is observed as about $400 \mathrm{ppm}$ [18]. Content of $\mathrm{CO}_{2}$ in the air is admittedly too low to create carbonated waters. The formation of mineralized waters in the discussed area occurs mostly in the zones of intense inflow of carbon dioxide from the depth of the rock mass, i.e., in the zones of strong cracks. The origin of 
groundwater is related to the dehydration of clay minerals in metamorphic processes, these waters migrate to the ground surface and mix with local meteoric waters. The migration of dehydrated waters and $\mathrm{CO}_{2}$ to the surface is enhanced by numerous faults. The upward flow of water results from pressures higher than hydrostatic. No changes in the flow rates of $\mathrm{CO}_{2}$ are observed. Therefore, its supply can be regarded as constant in terms of human generations. The waters that have not come into contact with carbon dioxide along the path of the flow from the supply area reach wells as natural waters. Continuous inflow of carbon dioxide and of waters of atmospheric origin contribute to continuous renewability of carbonated water resources in this region [9-10, 19-20].

The similar, well-known processes of the dissolution of rocks are observed by $\mathrm{CO}_{2}$ enrichment of the
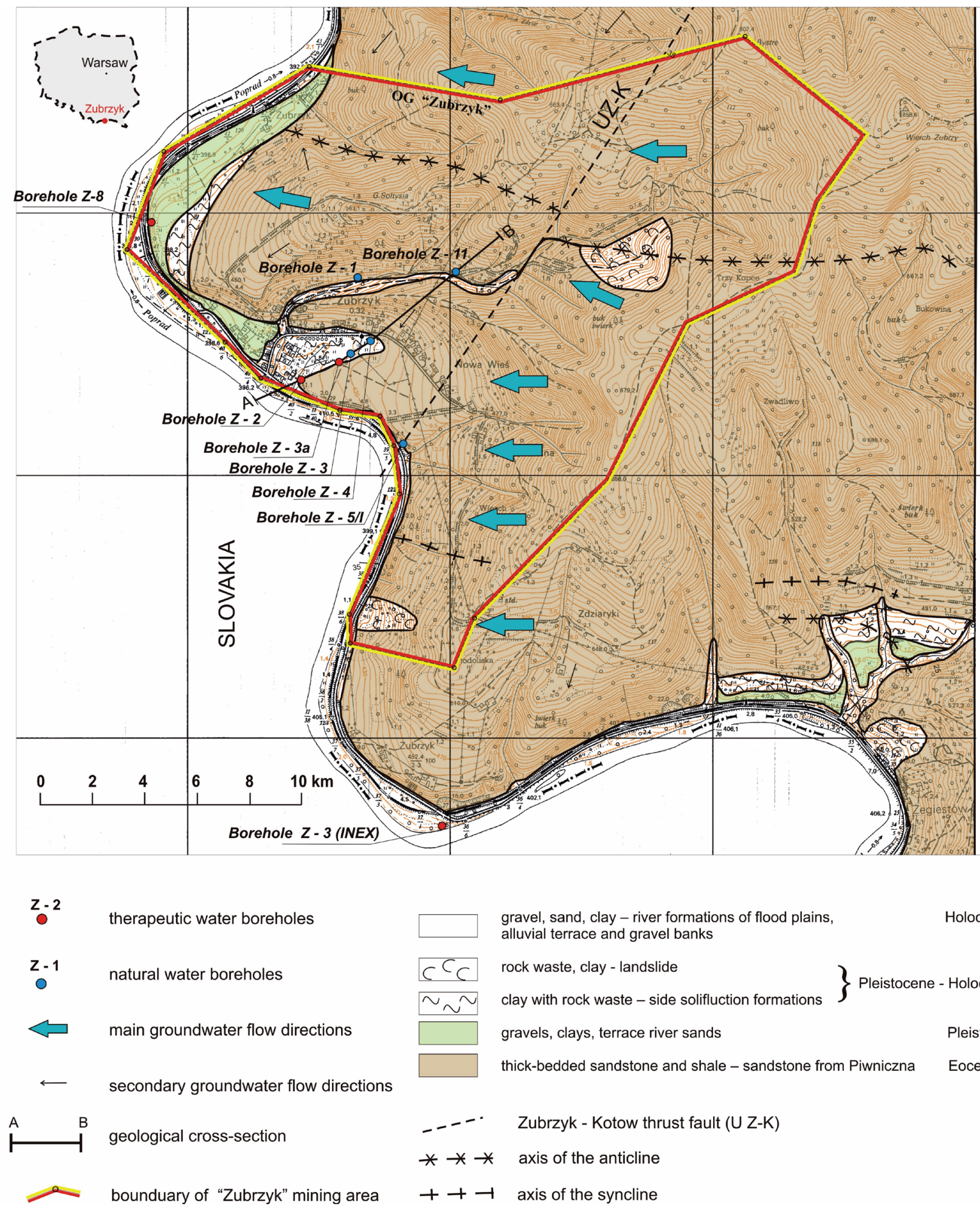

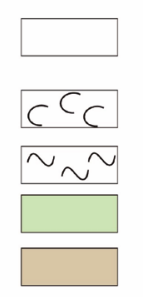

gravel, sand, clay - river formations of flood plains, alluvial terrace and gravel banks

rock waste, clay - landslide

clay with rock waste - side solifluction formations

\} Pleistocene - Holocene

gravels, clays, terrace river sands

Pleistocen

thick-bedded sandstone and shale - sandstone from Piwniczna

Eocene

\section{_- $\quad$ Zubrzyk - Kotow thrust fault (U Z-K) \\ $* * *$ axis of the anticline \\ $+\rightarrow \rightarrow$ axis of the syncline}

Fig. 1. Geological map noting locations of boreholes in the Zubrzyk area. 
water infiltrated into the aquifer [21]. The scale of this mechanism is less than when the carbon dioxide is of abyssal origin [22-23]. In the Carpathians the main source of $\mathrm{CO}_{2}$ is from metamorphism or diagenesis of carbonate rocks. A part of $\mathrm{CO}_{2}$ is also of magmatic origin. These processes occur in the crust of the earth. Deep-seated $\mathrm{CO}_{2}$ is of metamorphic origin, as indicated by $\delta^{13} \mathrm{C}\left(\mathrm{CO}_{2}\right)$ values close to $-1 \%$ [22], although some contribution of magmatic $\mathrm{CO}_{2}$ is possible as suggested by ${ }^{3} \mathrm{He} /{ }^{4} \mathrm{He}$ data
[24]. Carbonated waters in the Carpathians are very common and so many attempts have been made to explain the origin of $\mathrm{CO}_{2}$ [24-28].

\section{Material and Methods}

Groundwaters within the Zubrzyk Exploration Region have been found in eight boreholes that are currently held

\section{A}

\section{SW}

B

NNE
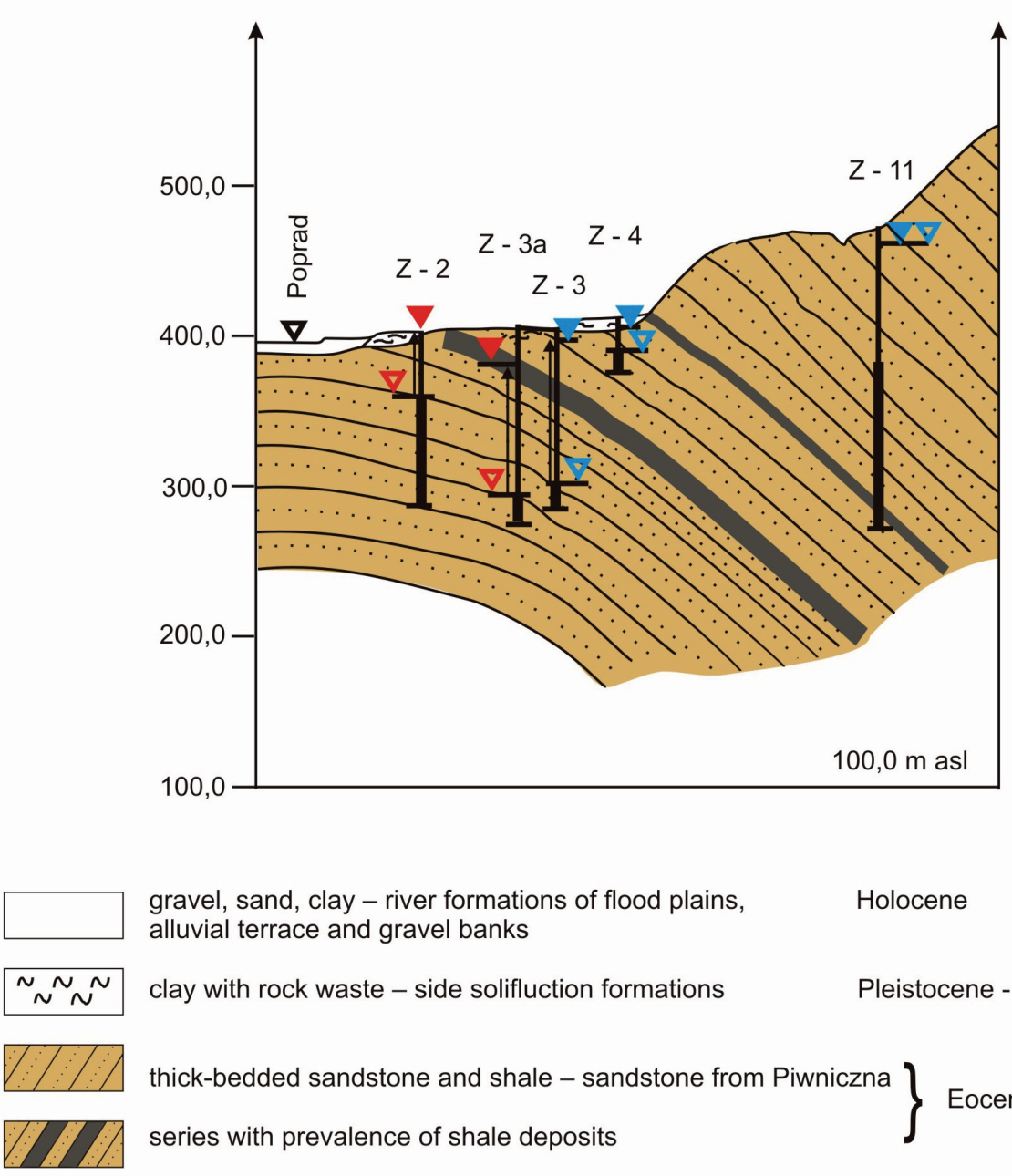

gravel, sand, clay - river formations of flood plains alluvial terrace and gravel banks

clay with rock waste - side solifluction formations

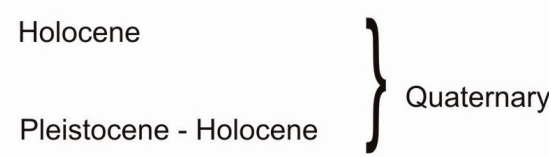

thick-bedded sandstone and shale - sandstone from Piwniczna

series with prevalence of shale deposits

Eocene

\} Tertiary

\section{Boreholes}

Z - 2 the name of the borehole

the stable water table
the drilled water table
the water-bearing stratum in the intake

Fig. 2. Zubrzyk area geological section. 
Table 1. Boreholes in the "Zubrzyk" mining area.

\begin{tabular}{|c|c|c|c|c|c|c|c|}
\hline $\begin{array}{l}\text { Name of } \\
\text { the well }\end{array}$ & $\begin{array}{l}\text { Status } \\
\text { of the } \\
\text { intake }\end{array}$ & $\begin{array}{c}\text { Depth of } \\
\text { the well } \\
{[\mathrm{m}]}\end{array}$ & $\begin{array}{c}\text { Groundwater table: } \\
\text { stagnant } \\
\text { drilled } \\
{[\mathrm{m} \mathrm{bgl}]}\end{array}$ & $\begin{array}{c}\text { Static } \\
\text { ordinate of } \\
\text { water table } \\
{[\mathrm{m} \text { asl }]}\end{array}$ & $\begin{array}{c}\text { Exploitation } \\
\text { resources } \\
\mathrm{Q} \\
{\left[\mathrm{m}^{3} / \mathrm{h}\right]}\end{array}$ & $\begin{array}{l}\text { Maximum allowed } \\
\text { depression cause by } \\
\text { pumping of the well } \\
\mathrm{S} \\
{[\mathrm{m}]}\end{array}$ & Notes \\
\hline$Z-2$ & $\mathrm{C}$ & 115.0 & $\frac{+0.85}{42.00}$ & 405.35 & 2.8 & 57.92 & $\begin{array}{c}\text { Therapeutic } \\
\text { water }\end{array}$ \\
\hline$Z-3 a$ & $\mathrm{C}$ & 131.5 & $\frac{22.20}{115.00}$ & 393.10 & 1.1 & 54.65 & $\begin{array}{c}\text { Therapeutic } \\
\text { water }\end{array}$ \\
\hline Z-8 & $\mathrm{C}$ & 143.0 & $\frac{2.25}{65.00}$ & 398.20 & 3.0 & 51.30 & $\begin{array}{c}\text { Therapeutic } \\
\text { water }\end{array}$ \\
\hline$Z-1$ & $\mathrm{C}$ & 150.0 & $\frac{11.40}{41.00}$ & 428.60 & 5.0 & 73.60 & $\begin{array}{c}\text { Natural } \\
\text { water }\end{array}$ \\
\hline$Z-3$ & $\mathrm{C}$ & 123.0 & $\frac{4.70}{97.00}$ & 409.30 & 2.46 & 57.95 & $\begin{array}{c}\text { Natural } \\
\text { water }\end{array}$ \\
\hline$Z-4$ & $\mathrm{C}$ & 26.0 & $\frac{4.75}{13.00}$ & 413.15 & 3.9 & 7.60 & $\begin{array}{c}\text { Natural } \\
\text { water }\end{array}$ \\
\hline $\mathrm{Z}-5 / \mathrm{I}$ & $\mathrm{C}$ & 150.0 & $\frac{1.10}{49.00}$ & 412.30 & 4.0 & 23.71 & $\begin{array}{l}\text { Natural } \\
\text { water }\end{array}$ \\
\hline$Z-11$ & $\mathrm{~N}$ & 200.0 & $\frac{9.70}{9.70}$ & 447.69 & 3.0 & 24.05 & $\begin{array}{c}\text { Natural } \\
\text { water }\end{array}$ \\
\hline
\end{tabular}

$\mathrm{C}$ : active, $\mathrm{N}$ : unused

by MASSPOL. Table 1 presents their characteristics on the basis of the archived materials of the Zubrzyk Mining Plant, and their location is shown in Fig. 1. Actual chemical analyses of the waters from active boreholes are shown in Table 2. The Z-11 borehole is not exploited currently.

Static surfaces of waters in flysch formations in Z-3a and Z- 8 boreholes is subartesian and in the Z-2 borehole artesian.

\section{Boreholes with Therapeutic Water}

The Zubrzyk area is located in the so-called "central hydrochemical zone" of the Carpathian mineral waters province. Fresh waters occur along with therapeutic waters in this zone. Vertical hydrochemical zonation is usually found here and which is manifested through mineralisation of waters increasing with depth and, in general, decreasing output [8]. Therapeutic waters within the Zubrzyk Exploration Region are taken from three boreholes: Z-2, Z-3a, and Z-8. Outside of OG Zubrzyk, therapeutic waters are taken from the Z-3 borehole owned by INEX, currently not exploited.

The Z-2 borehole was the first borehole with therapeutic water in the discussed region. It was completed in 2001 down to a depth of $115.0 \mathrm{~m}$ (Fig. 2). The original exploitation resources of this borehole were: $\mathrm{Qe}=4.6 \mathrm{~m}^{3} / \mathrm{h}$ with the cone of depression (the depression in the water table cause by pumping from a well) $\mathrm{Se}=42.85 \mathrm{~m}$. During the drilling and research work, on the completion (in 2007) of another borehole with therapeutic water (named
Z-3a, with a depth of $131.5 \mathrm{~m}$; Fig. 2), the connection between these boreholes was observed. Therefore, the exploitation resources of both boreholes in conditions of their co-operation had to be documented. The final assessment of the exploitation resources of the $\mathrm{Z}-2$ borehole is: Qe $=2.8 \mathrm{~m}^{3} / \mathrm{h}$ and $67.2 \mathrm{~m}^{3} /$ day with the depression $\mathrm{Se}=57.92 \mathrm{~m}$, which corresponds to the ordinate $\mathrm{H}=348.79 \mathrm{~m}$ asl. The output of the Z-3a borehole is: $Q$ e $=1.1 \mathrm{~m}^{3} / \mathrm{h}$, i.e., $26.4 \mathrm{~m}^{3} /$ day with the depression $\mathrm{Se}=54.65 \mathrm{~m}$, which corresponds with the ordinate $\mathrm{H}=338.45 \mathrm{~m}$ a.s.l. The third borehole with therapeutic water, Z-8, was executed in 2015 to a depth of $143 \mathrm{~m}$. Its confirmed output is $3.0 \mathrm{~m}^{3} / \mathrm{h}$ and $72.0 \mathrm{~m}^{3} / \mathrm{d}$ with the depression of $\mathrm{Se}=51.30 \mathrm{~m}$.

The Z-3 borehole owned by INEX was executed in 2005 , with its exploitation resources being determined as late as 2016 , in the volume of $3.8 \mathrm{~m}^{3} / \mathrm{h}$ and $91.2 \mathrm{~m}^{3} / \mathrm{d}$ with the depression of $\mathrm{Se}=21.25 \mathrm{~m}$.

\section{Physical and Chemical Characteristics of Therapeutic Waters}

\section{Z-2 Borehole}

On the basis of the physical and chemical examination of water from borehole Z-2, done in September 2014, its reaction was found to be weakly acid $\mathrm{pH}=6.04$. The $\mathrm{HCO}_{3}{ }^{-}$ion is the dominant anion $(94.0 \% \mathrm{meq})$, and calcium (42.0\% meq), magnesium (33.9\% meq), and sodium (22.4 $\%$ meq) are the dominant cations. Carbon dioxide content measured in the field with the Karat apparatus was 1,130 $\mathrm{mg} / \mathrm{dm}^{3}$. It is highly mineralised water with $1,729.9 \mathrm{mg} /$ 
Table 2. Chemical data of waters in the Zubrzyk Minning Plant.

\begin{tabular}{|c|c|c|c|c|c|c|c|c|c|}
\hline \multirow{2}{*}{$\begin{array}{l}\text { Name of } \\
\text { the well }\end{array}$} & \multirow{2}{*}{$\begin{array}{l}\text { Total disso- } \\
\text { lved solids } \\
{\left[\mathrm{mg} / \mathrm{dm}^{3}\right]}\end{array}$} & \multirow{2}{*}{$\begin{array}{c}\text { Type of water } \\
{[\% \text { mval }]}\end{array}$} & $\mathrm{Ca}^{2+}$ & $\mathrm{Mg}^{2+}$ & $\mathrm{Na}^{+}$ & $\mathrm{HCO}^{3-}$ & $\mathrm{Cl}^{-}$ & $\mathrm{SO}_{4}^{2-}$ & $\mathrm{CO}_{2}$ \\
\hline & & & \multicolumn{7}{|c|}{$\left[\mathrm{mg} / \mathrm{dm}^{3}\right]$} \\
\hline \multicolumn{10}{|c|}{ Therapeutic waters } \\
\hline $\mathrm{Z}-2$ & 1729,9 & $0,2 \%$ carbonated water $\mathrm{HCO}_{3} \mathrm{Ca}-\mathrm{Na}-\mathrm{Mg}$ & 181,3 & 88,8 & 111,1 & 1241 & 9,2 & 48,0 & 1130 \\
\hline $\mathrm{Z}-3 \mathrm{a}$ & 2179,4 & $0,2 \%$ carbonated water $\mathrm{HCO}_{3}-\mathrm{Na}-\mathrm{Mg}-\mathrm{Ca}$ & 158,7 & 100,1 & 221,9 & 1627 & 2,7 & $<3,5$ & 1334 \\
\hline$Z-8$ & 1644,2 & $\begin{array}{l}0,2 \% \text { water containing carbon dioxide } \\
\qquad \mathrm{HCO}_{3}-\mathrm{Na}-\mathrm{Mg}\end{array}$ & 50,1 & 75,6 & 251,4 & 1223 & 5,8 & 17,6 & 927 \\
\hline \multicolumn{10}{|c|}{ Natural waters } \\
\hline$Z-1$ & 337,2 & $0,03 \%$ water $\mathrm{HCO}_{3}-\mathrm{Ca}-\mathrm{Mg}$ & 33,74 & 19,74 & 16,88 & 201,5 & 5,8 & 32,73 & 0,0 \\
\hline$Z-3$ & 622,7 & $0,06 \%$ water $\mathrm{HCO}_{3}-\mathrm{Ca}-\mathrm{Mg}$ & 91,08 & 30,54 & 19,85 & 403,0 & 10,1 & 37,73 & 0,0 \\
\hline$Z-4$ & 389,8 & $0,04 \%$ water $\mathrm{HCO}_{3}-\mathrm{Ca}-\mathrm{Mg}$ & 68,86 & 10,22 & 4,42 & 269,0 & 5,1 & 10,09 & 0,0 \\
\hline$Z-5 / I$ & 320,1 & $0,03 \%$ waterHCO $3-\mathrm{Ca}-\mathrm{Mg}-\mathrm{Na}$ & 34,54 & 14,93 & 20,15 & 205,5 & 2,2 & 15,27 & 0,0 \\
\hline
\end{tabular}

$\mathrm{dm}^{3}$ mineralisation, $\mathrm{HCO}_{3}-\mathrm{Ca}-\mathrm{Mg}-\mathrm{Na}$ carbonated type. Detectable content of nitric compounds has not been found.

The results of chemical analysis of the sample of water is shown by simplified form of the Kurlov formula, which reads as follows [29]:

$$
M, G, S p \frac{\text { anions }}{\text { cations }} T, p H, Q
$$

...where M (mineralization) stands for total dissolved solids (TDS), with its content given in the upper script in $\mathrm{g} / \mathrm{L}, \mathrm{G}$ is the gas content in $\mathrm{g} / \mathrm{L}$, Sp represents one or more selected specific components with concentrations given in the upper scripts (formerly lower scripts were used) in $\mathrm{g} / \mathrm{L}$ or $\mathrm{mg} / \mathrm{L}$, anions and cations represent ion contents with concentrations greater than $1 \%$ in decreasing order of equivalent percentages (\%meq), $\mathrm{T}$ is temperature in ${ }^{\circ} \mathrm{C}$, and $\mathrm{Q}$ is the outflow rate in $\mathrm{m}^{3} / \mathrm{min}$, if applicable. $\mathrm{G}, \mathrm{Sp}$, $\mathrm{T}, \mathrm{pH}$, and $\mathrm{Q}$ as well as percentages of major ions below $10 \%$ or $20 \%$ can be omitted if not needed. The Kurlov formula was chosen from available graphical methods of presentation of chemical data. That formula is well known and often is used in Central and Eastern European countries, and its advantages are worth advertising to a global audience: simple presentations of major and minor components with a chosen degree of accuracy and information on gas $\left(\mathrm{CO}_{2}\right)$, which are of importance for a process under consideration, and information on total mineralization (TDS).

The results of chemical analysis from the Z-2 borehole presented with the Kurlov formula are as follows:

$$
\text { Z-2 borehole } \mathrm{M}^{1,73} \mathrm{CO}_{2}{ }^{1130} \frac{\mathrm{HCO}_{3}{ }^{94} \mathrm{SO}_{4}{ }^{5} \mathrm{Cl}^{1}}{\mathrm{Ca}^{42} \mathrm{Mg}^{34} \mathrm{Na}^{22} \mathrm{~K}^{1}}
$$$$
\text { (22.09.2014) }
$$

\section{Z-3a Borehole}

The physical and chemical examination of water from the Z-3a borehole, done also in September 2014, showed its reaction to be weakly-acid with $\mathrm{pH}=6.44$. The $\mathrm{HCO}_{3}{ }^{-}$ion is the dominant anion $(99.7 \% \mathrm{meq})$, with sodium (36.7\%meq), magnesium (31.3\%meq), and calcium $(30.1 \% \mathrm{meq})$ being the dominant cations. Content of carbon dioxide measured in the field with the Karat apparatus was $1,334 \mathrm{mg} / \mathrm{dm}^{3}$. It is highly mineralised water with $2,179.4 \mathrm{mg} / \mathrm{dm}^{3}$ mineralisation, $\mathrm{HCO}_{3}-\mathrm{Na}-$ $\mathrm{Mg}-\mathrm{Ca}$ carbonated type. Detectable content of nitric compounds has not been found.

The results of chemical analysis of the sample of water from the Z-3a borehole presented with the Kurlov formula are as follows:

$$
\mathrm{M}^{2,18} \mathrm{CO}_{2}{ }^{1334} \frac{\mathrm{HCO}_{3}{ }^{100}}{\mathrm{Na}^{37} \mathrm{Mg}^{31} \mathrm{Ca}^{30} \mathrm{~K}^{1}}
$$$$
\text { (22.09.2014) }
$$

\section{Z-8 Borehole}

On the basis of the physical and chemical examination of water done in June 2015, its reaction was found to be weak-acid $\mathrm{pH}=6.85$. The hydrogencarbonate ion is the dominant anion $(96.7 \% \mathrm{meq})$, with sodium (54.4\% meq), and magnesium $(31.0 \% \mathrm{meq})$ being the dominant cations. It is water with mineralisation of $1,673.5 \mathrm{mg} / \mathrm{dm}^{3}$, containing carbon dioxide $\mathrm{HCO}_{3}-\mathrm{Na}-\mathrm{Mg}$. The results of chemical analysis of the sample of water from the Z-8 borehole presented with the Kurlov formula are as follows:

$$
\mathrm{M}^{1,67} \mathrm{CO}_{2}{ }^{927} \frac{\mathrm{HCO}_{3}{ }^{97} \mathrm{Cl}^{2} \mathrm{SO}_{4}{ }^{1}}{\mathrm{Na}^{54} \mathrm{Mg}^{31} \mathrm{Ca}^{12} \mathrm{~K}^{1}}
$$

$(15.06 .2015)$ 

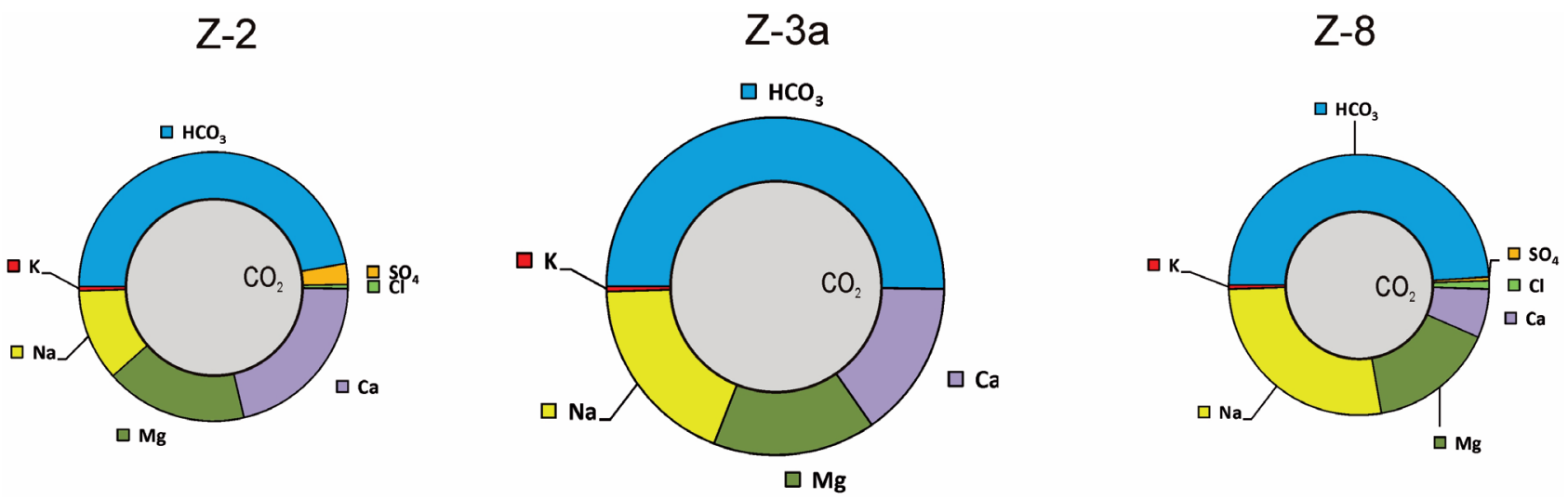

Fig. 3. UDLUFT pie charts of therapeutic waters of the Zubrzyk Region.

Therapeutic water from the Z-2, Z-3a, and Z-8 boreholes are presented with UDLUFT pie charts in Fig. 3.

\section{Results of Quality and Discussion of Stability of Chemical Composition}

Therapeutic waters from the Zubrzyk area boreholes Z-2, Z-3a, and Z-8 are subject to periodic checking of physical and chemical parameters. In the period from 2004 to 2014 the analyses were done by the laboratory of the University of Science and Technology in Kraków. The Z-2 and Z-3a boreholes have been exploited for several years, which allows us to assess stability of chemical composition of the therapeutic waters and to formulate forecasts in this respect. The Z-8 borehole, completed in 2015, has not been observed long enough to provide grounds for clear determination of trends in maintaining stable chemical composition of the water.

\section{Z-2 Borehole}

Based on the results of the physical and chemical analyses made available by MASSPOL Sp. z o.o., an analysis of changes in the parameters of therapeutic water from the Z-2 borehole was conducted. Electrical conductivity of therapeutic water during the period from 2004 to mid-2014 decreased from ca. $2.3 \mathrm{mS} / \mathrm{cm}$ to ca. $1.2 \mathrm{mS} / \mathrm{cm}$ (Fig. 4). Despite quite significant fluctuations, water maintained more than $1,000 \mathrm{mg}$ of components dissolved in $1 \mathrm{dm}^{3}$ - enough to be classified as mineralised water. Conductivity increased after the end of 2014, now mostly ranging from $1.0 \mathrm{mS} / \mathrm{cm}$ to $2.0 \mathrm{mS} / \mathrm{cm}$.

Content of $\mathrm{CO}_{2}$ in water from the Z-2 borehole gradually decreased over 2004-16, with major fluctuations observed during 2007-11 in content from ca. $600 \mathrm{mg} / 1$ to $1,700 \mathrm{mg} / \mathrm{dm}^{3}$. From the end of 2011 until the end of 2014 , content of $\mathrm{CO}_{2}$ was recorded on a relatively stable level in the range of $900 \mathrm{mg} / 1$ to $1,100 \mathrm{mg} / \mathrm{dm}^{3}$. Since 2015 fluctuations have been basically higher, in the range 1,000-1,400 mg/l (Fig. 5).

Analysing the above charts, one has to conclude that the values of the determined parameters received during the original documentation in 2002 and the subsequent combined pumping in 2007 are considerably higher than those obtained in recent years. The cause of this is the reduced output of the borehole, thus failing to achieve the conditions achieved during long exploitation and combined pumping. During 2008-15 the boreholes with

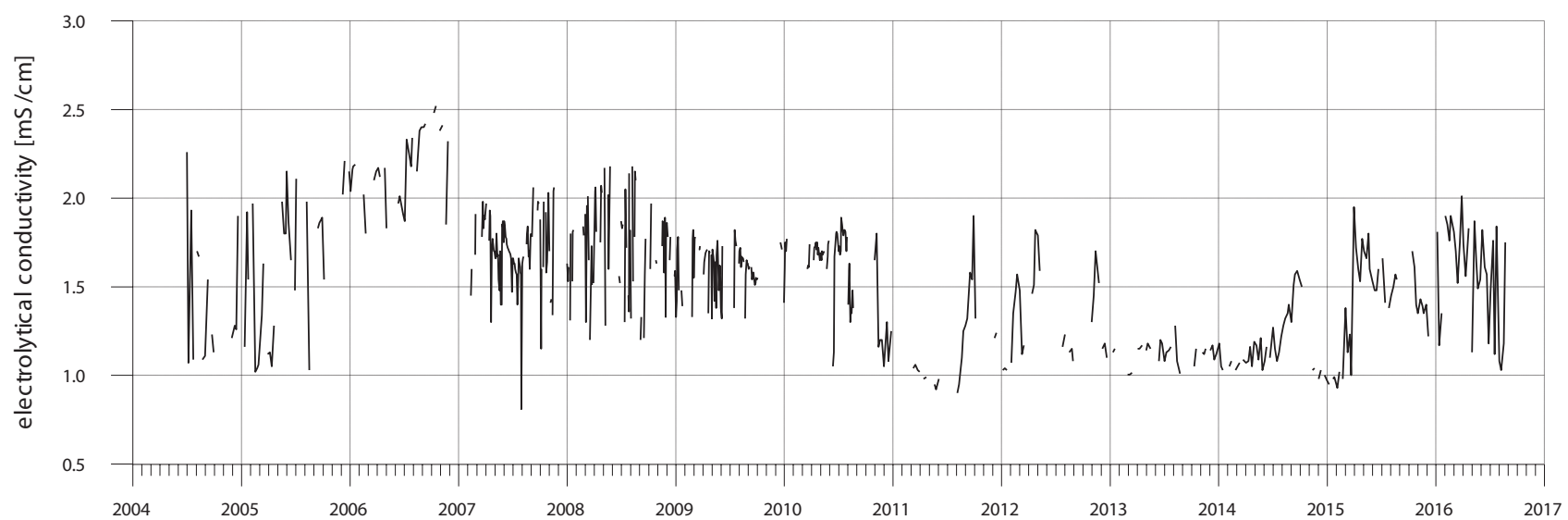

Fig. 4. Changes in electrolytic conductivity in the Z-2 borehole. 


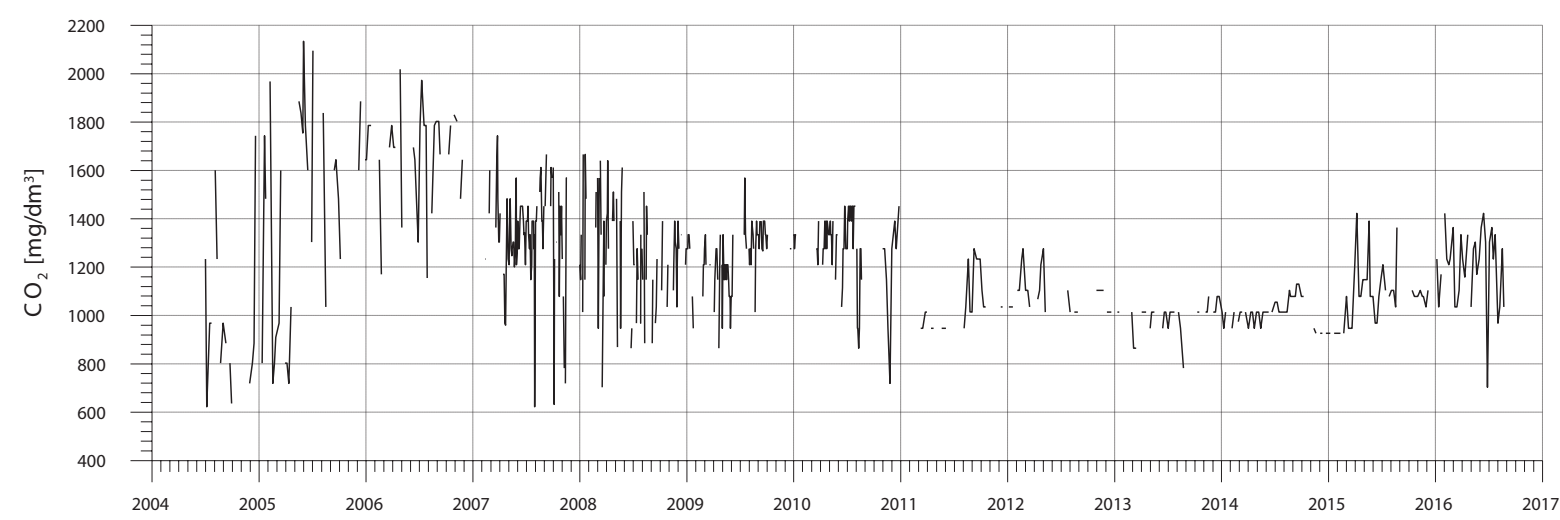

Fig. 5. Changes in carbon dioxide content in the Z-2 borehole.

therapeutic water were exploited on a smaller scale than those with regular water, located close to the Z-2 borehole. The exploitation of the borehole at the maximum allowed cone of depression according to hydrogeological documentation, equal to the exploitation output of the borehole, may be expected to allow obtaining increased depression and therefore higher mineralisation and $\mathrm{CO}_{2}$ content, as confirmed with the results of the analyses since the beginning of 2015 .

\section{Z-3a Borehole}

Analysing the results of the physical and chemical examinations of therapeutic water from the Z-3a borehole was conducted by the laboratory of the University of Science and Technology in Kraków during the period 2011-15. Mineralisation of water from the period documenting the resources and subsequent exploitation may be regarded as not changing substantially: it has been maintained at a similar level of ca. 2,100-2,300 mg/l. This corresponds with the value of electrolytical conductivity of water from the Z-3a borehole, which is in the range $2.0 \mathrm{mS} / \mathrm{cm}$ to $2.3 \mathrm{mS} / \mathrm{cm}$. Electrolytical conductivity has been slightly decreasing since early 2015 and is at the level of about $2.0 \mathrm{mS} / \mathrm{cm}$ (Fig. 6).

Content of $\mathrm{CO}_{2}$ in water has not changed during the period of exploitation of borehole Z-3a and is fluctuating slightly from ca. $1,000 \mathrm{mg} / \mathrm{dm}^{3}$ to $1,600 \mathrm{mg} / \mathrm{dm}^{3}$ (Fig. 7).

Small fluctuations of the above physical and chemical parameters of therapeutic water from the Z-3a well are related to periods of irregular exploitation, which means that the wells are operated under unstable conditions.

\section{Z-8 Borehole}

Exploitation of the Z-8 borehole with therapeutic water, drilled in 2015, started in early 2016. The database of the executed physical and chemical analyses thus covers only seven months. During this period, the value of electrolytical conductivity was maintained at a stable level in the range 1.6-1.8 mS/cm (Fig. 8).

Measurements of the content of carbon dioxide during the observation period were uniformly equal to $622 \mathrm{mg} / 1$, except for one measurement in June 2016, when $865 \mathrm{mg} / 1$ was recorded (Fig. 9).

\section{Zubrzyk Therapeutic Waters in View of Krynica Subunit Groundwater}

Therapeutic waters in the Zubrzyk catchment are typical of the Polish Outer Carpathians as the carbonated waters and waters containing carbon dioxide types, originating under complex gas and water conditions,

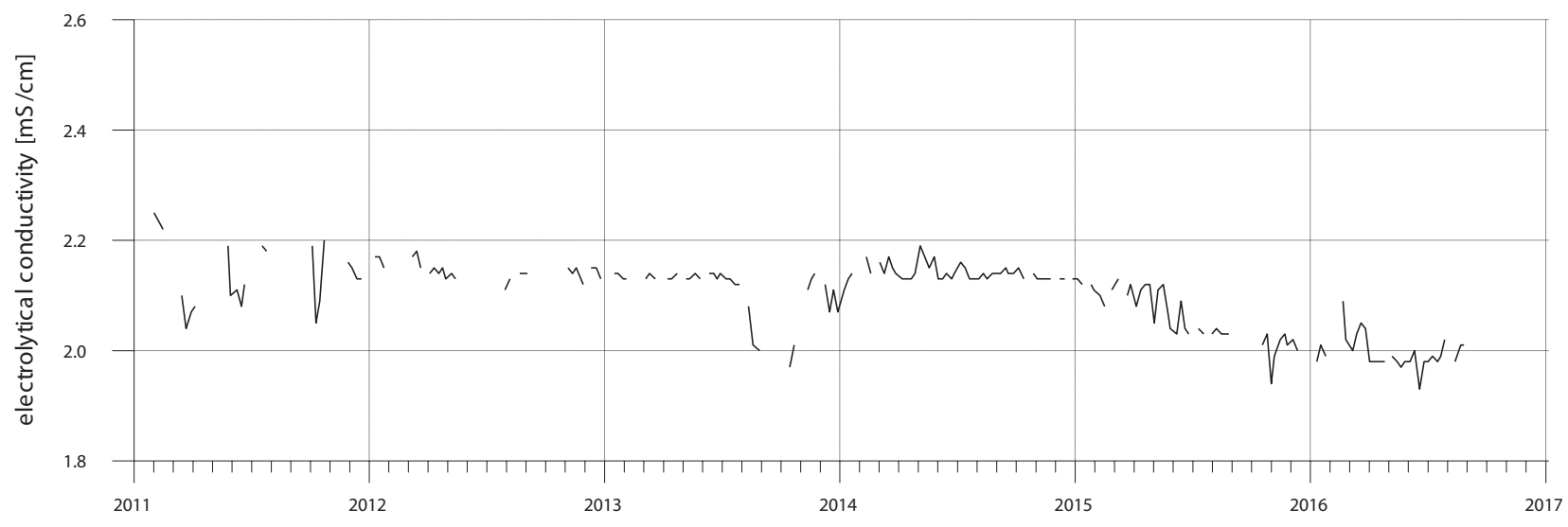

Fig. 6. Changes in electrolytic conductivity in the Z-3a borehole. 


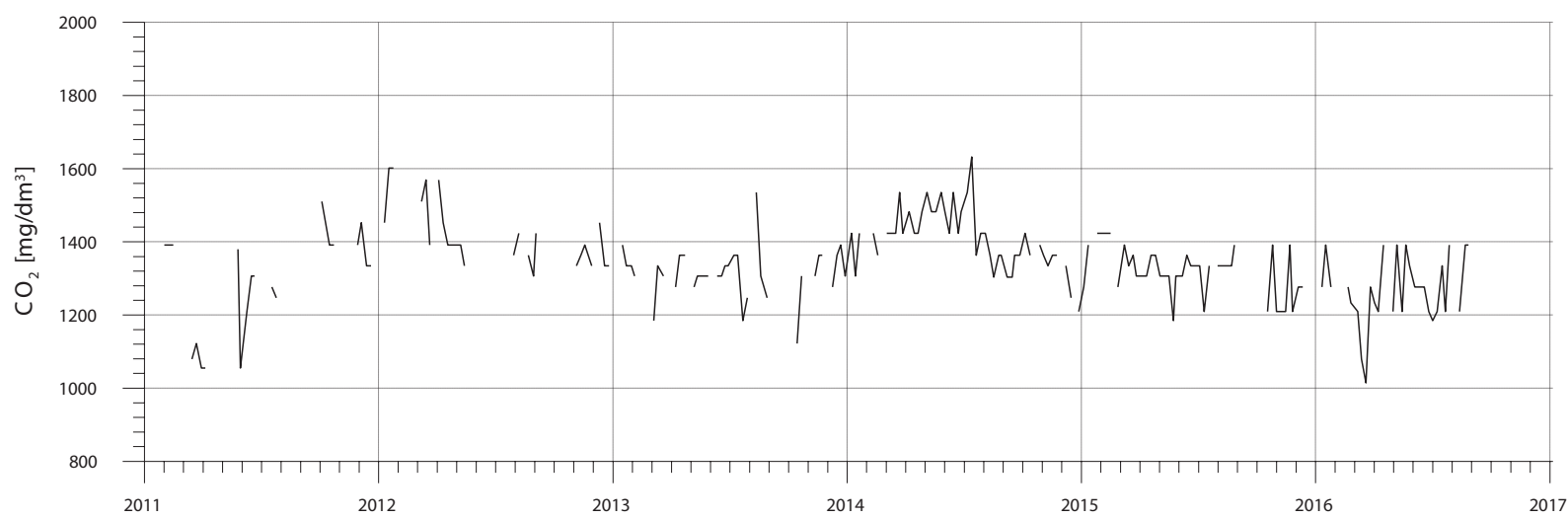

Fig. 7. Changes in carbon dioxide content in the Z-3a borehole.

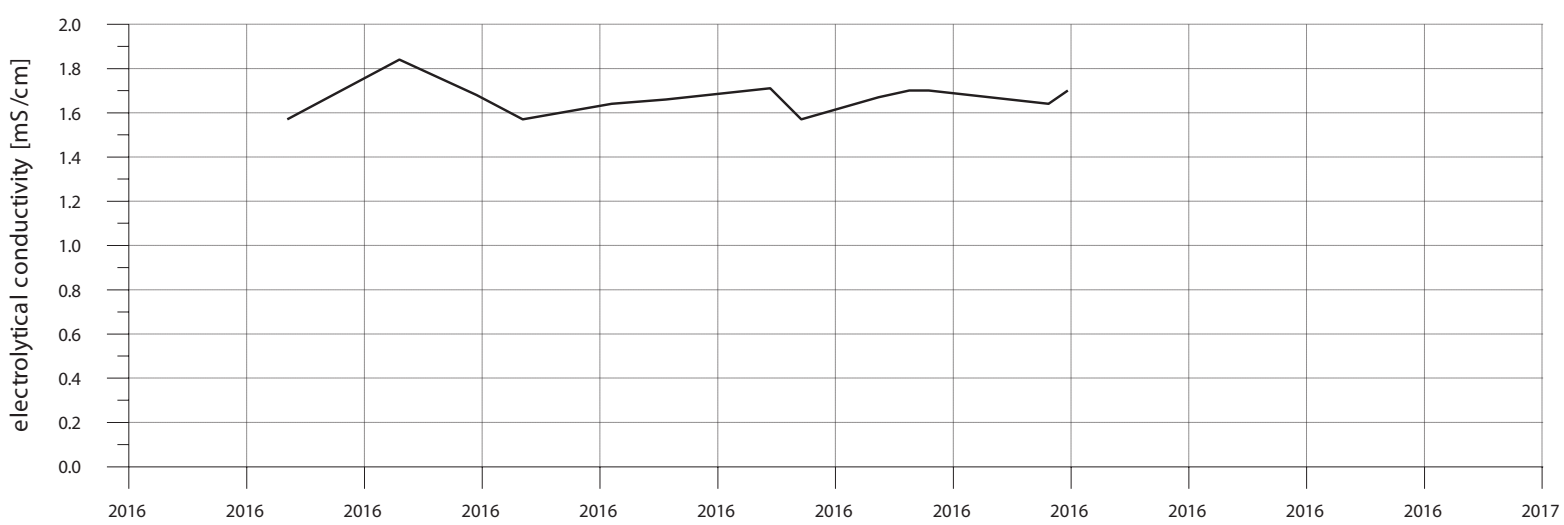

Fig. 8. Changes in electrolytic conductivity in the Z-8 borehole.

when subduction carbon dioxide reaches the stream of groundwaters migrating in the rock environment [10]. All the discussed boreholes of therapeutic waters in the Zubrzyk catchment are produced within sandstone and shale facies, referred to as sandstone from Piwniczna, occurring continuously from Piwniczna to Zubrzyk and Muszyna to Leluchów. Water in the Z-2 and Z-3a boreholes is classified as carbonated waters (with content of $\mathrm{CO}_{2}$ over $1,000 \mathrm{mg} / \mathrm{l}$ ), and water from the Z-8 borehole is a water-containing carbon dioxide.
The Carpathian carbonated waters are commonly divided into two genetic groups, i.e., those of the ordinary type present in zones of shallow water circulation with low mineralisation, and those of the chloride type present in deeper aquifers with high mineralisation [10]. Zubrzyk shallow-seated waters belong mainly to the $\mathrm{HCO}_{3}-(\mathrm{Ca})$ $(\mathrm{Mg})$ hydrochemical type, without high $\mathrm{Cl}$ concentration.

On the basis of the origin of chemical composition (of carbonated waters and waters containing carbon dioxide types), all Carpathian carbonated waters are

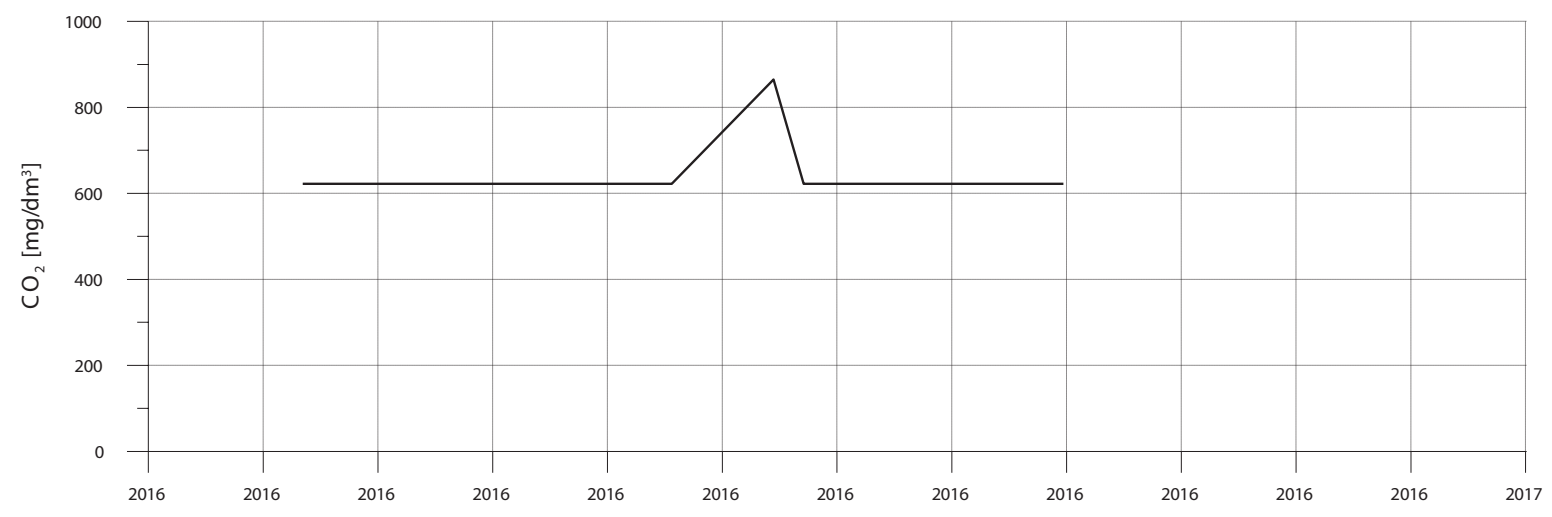

Fig. 9. Changes in carbon dioxide content in the Z-8 borehole. 
classified in four main groups [9]. In the area of Poprad (in Krynica subunit), waters have been documented with total dissolved solids in the range $0.3-29.0 \mathrm{~g} / \mathrm{dm}^{3}$ in the $\mathrm{HCO}_{3}-(\mathrm{Ca})-(\mathrm{Mg})-(\mathrm{Na})+\mathrm{CO}_{2}+(\mathrm{I})+(\mathrm{Fe})+\left(\mathrm{H}_{2} \mathrm{SiO}_{3}\right)$ type [9], representing mostly groups III and IV. Group III includes waters with mineralisation of $1-6 \mathrm{~g} / \mathrm{dm}^{3}$ of the $\mathrm{HCO}_{3}-\mathrm{Ca}$ or $\mathrm{HCO}_{3}-(\mathrm{Ca})-(\mathrm{Mg})$ types. Waters of this group are related to the most shallow flysche formations through which water runs relatively fast, thus shortening the contact of water with rock. Group IV includes waters related to the zone of mixing of waters of very high mineralisation (groups I and II) with waters from Group III. These waters occur in the direct neighbourhood of highly mineralised waters, at lower depths.

Therapeutic waters of the Zubrzyk region are in general of the $\mathrm{HCO}_{3}-\mathrm{Ca}-\mathrm{Mg}-\mathrm{Na}$ type, with a varied order of cations. A similar type of water occurs in the area of Piwniczna, but also in the boreholes in Powroźnik and Muszyna. $\mathrm{HCO}_{3}-\mathrm{Ca}-\mathrm{Mg}-\mathrm{Na}$ type (in the $\mathrm{Z}-2$ borehole in Zubrzyk) was reached through the boreholes P-10 in Powroźnik and Złockie 2 in Muszyna. $\mathrm{HCO}_{3}-\mathrm{Na}-\mathrm{Mg}$ type water is taken from the Z-8 borehole in Zubrzyk, and the same type of water has been reached in the Złockie 9 borehole in Muszyna.

\section{Conclusions}

Therapeutic waters from the Poprad Region within the Krynica Unit of the Magura Nappe have been appreciated for ages. Sale of bottled waters, both mineral and regular, continuously increases. Bottling companies thus look for new places to take in groundwaters. Exploitation of therapeutic waters in the area of Zubrzyk started as late as the early 21 st century. Thre boreholes are currently exploited, two of which (Z-2 and Z-3a) have the properly long stationary base observation to perform analyses of stability of chemical composition. The third borehole, called Z-8, is the latest borehole in this region included in the exploitation programme only several months ago. The analyses of the results of the tests conducted in the Z-2 and Z-3a boreholes, along with area development and condition of the environment, give reason to expect that the resulting therapeutic water will feature stability of chemical composition.

\section{Acknowledgements}

The authors would like to thank Masspol for sharing its database for this article.

\section{References}

1. OSZCZYPKO N., SALATA D., KONECNY P. Age and provenance of mica-schist pebbles from the Eocene conglomerates of the Tylicz and Krynica Zone (Magura Nappe, Outer Flysch Carpathians). Geologica Carpathica 67 (3), $257,2016$.
2. CIĘŻKOWSKI W., CHOWANIEC J., GÓRECKI W., KRAWIEC A., RAJCHEL L., ZUBER A. Mineral and thermal waters of Poland. Przegl Geol 58, 762, 2010.

3. RAJCHEL L. A "bottling basin" of mineral waters in the Poprad River valley. Geologia 35 (1-2), 278, 2009 [In Polish].

4. SATORA S., CHMIELOWSKI K., WAŁĘGA A. Balneological usage of the groundwater in the selected regions of South Poland. Acta Sci. Pol., Formatio Circumiectus 9 (4), 43, 2010 [In Polish].

5. CZOP M., MOTYKA J., RAJCHEL L. Contemporary hazards of the mineral and therapeutic waters from Poprad valley (Carpathians Mountains, South Poland). Biul Państw Inst Geol 445, 67, 2011 [In Polish].

6. CHOWANIEC J. [ed.], FREIWALD P.[ed.]. The atlas of hydrogeovariety in province of Malopolska. Urząd Marszałkowski, Kraków, Poland 2011 [In Polish].

7. PORWISZ B. The trail of therapeutic and thermal waters in province of malopolska. Urząd Marszałkowski, Kraków, Poland 2013 [In Polish].

8. RAJCHEL L. Carbonated waters of Łomnica nad Wierchomla in the Polish Carpathians. Biul Państw Inst Geol 445, 541, 2011 [In Polish].

9. RAJCHEL L. The carbonated waters and waters containing carbon dioxide of the Polish Carpathian. Wyd. AGH Kraków 2012 [In Polish].

10. RAJCHEL L. Occurences, chemistry and origin of carbonated waters and waters containing carbon dioxide of the Polish Carpathians. Biul Państw Inst Geol 456, 501, 2013 [In Polish].

11. CHOWANIEC J., GĄGULSKI T., GORCZYCA G., FREIWALD P., OPERACZ T. Therapeutic water of the Poprad valey - The Milik and Andrzejówka area. Biul Państw Inst Geol 465, 185, 2015 [In Polish].

12. OSZCZYPKO N., ŚLĄCZKA A., OSZCZYPKO-CLOWES M., OLSZEWSKA B. What was the Magura Ocean? Acta Geologica Polonica 65 (3), 319, 2015.

13. OSZCZYPKO-CLOWES M. Reworked nannofossils from the Lower Miocene deposits in the Magura Nappe (Outer Western Carpathians, Poland). Geologica Carpathica 63 (5), 407, 2012.

14. OSZCZYPKO N., OSZCZYPKO-CLOWES M., GOLONKA J., MARKO F. Oligocene-Lower Miocene sequences of the Pieniny Klippen Belt and adjacent Magura Nappe between Jarabina and the Poprad River (East Slovakia and South Poland): their tectonic position and palaeogeographic implications. Geological Quarterly 49 (4), 379, 2005.

15. OSZCZYPKO N., OSZCZYPKO-CLOWES M. Stages in the Magura Basin: a case study of the Polish sector (Western Carpathians). Geodinamica Acta 22, 83, 2009.

16. The Polish Act from 9 June 2011 - Geological and Minning Law (Dz. U. 2011 no 163 pos. 981).

17. CHOWANIEC J., ZUBER A. Diagenetic and other highly mineralized waters in the Polish Carpathians. Applied Geochemistry 24 (10), 1889, 2009.

18. CHMURA L., RÓŻAŃSKI K., NECKI J. M., ZIMNOCH M., KORUS A., PYCIA M. Atmospheric Concentrations of Carbon Dioxide in Southern Poland: Comparison of Mountain and Urban Environments. Pol. J. Environ. Stud. 17 (6), 859, 2008.

19. CHOWANIEC J., CIĘŻKOWSKI W., DULIŃSKI M., JÓZEFKO I., PORWISZ B., ZUBER A. Chemical facies of $\mathrm{CO}_{2}$-rich waters in the Flysch Carpathians versus water age. Biul Państw Inst Geol 436, 47, 2009 [In Polish]. 
20. ŻUREK A., ZMARŁA A. Hydrogeological coexistence of natural and mineral waters in Szczawiczny Potok catchmant near krynica (Beskid Sadecki). Biul Państw Inst Geol 456, 671, 2013 [In Polish].

21. SAOU A., MAZA M., SEIDEL J.L. Hydrogeochemical Processes Associated with Double Salinization of Water in an Algerian Aquifer, Carbonated and Evaporitic. Pol. J. Environ. Stud., 21 (4), 1013, 2012.

22. LEŚNIAK P., Open $\mathrm{CO}_{2}$-underground water system in the West Carpathians (south Poland) - Chemical and isotopic evidence. Chem. Geol. 49 (1-3), 275, 1985.

23. ZUBER A., CHOWANIEC J. Diagenetic and other highly mineralized waters in the Polish Carpathians. Applied Geochemistry, 24 (10), 1889, 2009.

24. LEŚNIAK P.M. Origin of carbon dioxide and evolution of $\mathrm{CO}_{2}$-rich waters in the West Carpathians. Acta Geol. Pol. 48, 342, 1998 .
25. DOWGIAŁŁO J. Occurence and use of mineral and thermal waters in Poland. Environ Earth Sci 67 (8), 2251, 2012.

26. DOWGIAŁŁO I., HAŁAS S., LIS J., SZARAN I. The isotopic composition of carbon in mineral waters of the Polish flysch Carpathians. Bull. Acad. Pol. Sci. Terre 23, 9, 1975.

27. DULIŃSKI M., GRABCZAK J., KOSTECKA A., WECŁAWIK S. Stable isotope composition of spelean calcites and gaseous $\mathrm{CO}_{2}$ from Tylicz (Polish Carpathians). Chem. Geol. 125, 271, 1995.

28. CIĘŻKOWSKI W. [ed.]. Occurrence, Documentation and Utilization of Endogenous Carbon Dioxide in Poland. Methodical quide. WTN, 220, 2002.

29. ZAPOROŻEC A. Graphical interpretation of water-quality data. Ground Water 10, 32, 1972. 